\title{
PREDIKSI KUNJUNGAN PASIEN BARU PERBANGSAL RAWAT INAP TAHUN 2015 DENGAN METODE ARIMA DI BLUD RSU BANJAR
}

\author{
${ }^{1}$ Muhammad Fuad Iqbal, ${ }^{2}$ Ida Wahyuni \\ ${ }^{1}$ Alumni Prodi D III PIKES Poltekkes Kemenkes Tasikmalaya Tahun 2014, bekerja di STIKES Bina \\ Permata Tangerang \\ ${ }^{2}$ Dosen Prodi D III PIKES Poltekkes Kemenkes Tasikmalaya \\ Email: ${ }^{1}$ iqbaleqbal@gmail.com, ${ }^{2}$ doonyboebz@yahoo.co.id
}

\begin{abstract}
Every patient who do treatments at the hospital will receive a medical record to document the history of their disease. Coloration of medical record documents can be applied to facilitate identification. Banjar BLUD'S hospital apply four variants colors that based on the type of disease. The provision of documents sometimes do not correspond with the number of its visits so that the color changed frequently with other colors. The purpose from this study is to determine the predictive results of the visits new hospitalization patient space in 2015 with an Autoregressive Integrated Moving Average (ARIMA) method. This is a descriptive quantitative study, conducted on a variable that is prediction of the visits new hospitalization patient space by 2015 in 14 inpatient room. The five years sample data of new patient visits based on the total sampling. Data's collection is in observation of documentation, and the analysis data computerized with the help of MINITAB applications. The results of prediction based on ARIMA method show there is an increase, decrease and fluctuate in some room. The results of prediction from the number of new patient visits from January 2009 to March 2014 showed a new patient visit is 23415. That number tends to decline from the year 2013 and up from the results prediction in 2014. Regard to planning the provision of medical record document, the number of provision is equal to the number of new patient visits, 23395 pieces. The conclusion from this study is the historical data plot hits on all wards showed fluctuating circumstances, so the ARIMA method suitable to use with the results forecast to decline from 2013 and up from 2014.
\end{abstract}

Keywords: Forecast, Visit, New Patient, ARIMA

\begin{abstract}
Abstrak
Setiap pasien yang berobat ke rumah sakit akan mendapatkan dokumen rekam medis untuk mendokumentasikan riwayat penyakitnya. Pewarnaan dokumen rekam medis dapat diterapkan unt uk mempermudah identifikasi. BLUD RSU Kota Banjar Provinsi Jawa Barat menerapkan empat varian warna yang berdasarkan jenis penyakit. Penyediaan dokumen kadangkala tidak sesuai dengan jumlah kunjungannnya sehingga sering dilakukan pergantian warna dokumen dengan warna yang lain. Tujuan dari penelitian ini adalah mengetahui hasil prediksi kunjungan pasien baru perbangsal rawat inap tahun 2015 dengan metode Autoregressive Integrated Moving Average (ARIMA). Penelitian ini bersifat deskriptif kuantitatif, dilakukan terhadap satu variabel yakni prediksi kunjungan pasien baru perbangsal rawat inap tahun 2015 di 14 bangsal. Sampel berjumlah lima tahun data kunjungan pasien baru berdasarkan total sampling. Pengumpulan data berupa observasi dokumentasi, dan analisis data secara komputerisasi dengan bantuan aplikasi MINITAB. Hasil Prediksi kunjungan berdasarkan metode ARIMA menunjukan terdapat kenaikan, penurunan dan fluktuatif di beberapa bangsal. Hasil prediksi dari jumlah kunjungan pasien baru dari bulan Januari 2009 sampai dengan Maret 2014 didapatkan hasil kunjungan adalah 23395 pasien baru. Jumlah tersebut cenderung turun dari tahun 2013 dan naik dari hasil prediksi tahun 2014. Berkaitan dengan perencanaan penyediaan dokumen rekam medis, maka jumlah penyediaan sama dengan jumlah kunjungan pasien baru yaitu sebesar 23415 buah. Simpulan dari penelitian ini adalah plot data historis kunjungan pada semua bangsal menunjukan keadaan fluktuatif, sehingga metode ARIMA cocok digunakan dengan hasil Prediksi menurun dari tahun 2013 dan naik dari tahun 2014.
\end{abstract}

Kata Kunci: Prediksi, Kunjungan, Pasien baru, ARIMA 


\section{PENDAHULUAN}

Rumah sakit merupakan satu sistem/bagian dari sistem pelayanan kesehatan, mempunyai tiga pilar otoritas yang masing-masing bekerja secara otonom namun harus terkoordinasi dalam sistem tersebut. Ketiga pilar tersebut adalah pilar pemilik, pilar profesional kesehatan dan pilar manajemen. Ketiga pilar tersebut masing-masing memiliki hierarki kekuasaan/ kewenangan yang mempunyai sifat dan karakteristik yang berbeda (Djojosoegito dalam Hatta, 2011). Pilar otoritas manajemen mempunyai kedudukan yang sentral dalam menyerasikan dua pilar otoritas lain. Keserasian dapat dicapai bila ada keterbukaan, kebersamaan dan keadilan dalam interaksi otoritas, dan salah satu faktor penentu suksesnya interaksi yang harmonis antara ketiga otoritas adalah data dan informasi (Hatta, 2011).

Unit rekam medis adalah salah satu unit penunjang medis yang mempersiapkan, mengumpulkan, mengolah dan menyediakan data serta menyajikannya dalam bentukinformasi untukmembantupengambilan keputusan. Data tersebut bersumber dari berbagai kegiatan pencatatan dan pendokumentasian hasil pemeriksaan, pengobatan, tindakan dan pelayanan lain yang telah diberikan kepada pasien oleh tenaga kesehat an yang dicatat pada dokumen rekam medis.

Rekam medis adalah milik rumah sakit, namun isinya milik pasien sehingga setiap pasien yang mendapatkan pelayanan medis di rumah sakit akan mendapatkan dokumen rekam medis untuk mendokumentasikan riwayat kesehatannya, termasuk didalamnya pasien rawat inap sebagai mana yang tercantum dalam Permenkes nomor 269 tahun 2008 pasal 3 ayat 2 "isi rekam medis untuk pasien rawat dan perawatan satu hari sekurang-kurangnya memuat 13 macam formulir yang wajib ada pada setiap dokumen".

Seiring bertambahnya jumlah populasi manusia dan keadaan perekonomian yang semakin maju, maka kesadaran masyarakat terhadap kesehatan semakin meningkat. Hal ini dapat meningkatkan jumlah pengunjung suatu rumah sakit. Meningkatnya kunjungan pasien harus diiringi dengan kesiapan pihak rumah sakit dalam pemenuhan fasilitas dan alat penunjang pelayanan, seperti halnya yang dijelaskan oleh Depkes RI (2007), peralatan yang dibutuhkan di bagian tempat pendaftaran rawat inap diantaranya dokumen rekam medis yang harus disesuaikan dengan jumlah pasien. Oleh karena itu pihak unit rekam medis harus melakukan kegiatan perencanaan yang matang salah satunya dengan melakukan kegiatan peramalan (forecasting) agar pelayanan tetap berjalan dengan baik.

Autoregressive Integreted Moving Average (ARIMA) merupakan salah satu metode time series bagian dari metode kuantitatif. ARIMA menggunakan nilai masa lalu dan sekarang dari variabel dependen untuk menghasilkan peramalan jangka pendek yang akurat, dengan memberikan informasi tentang ukuran kesalahan secara lengkap. Model ini sangat baik digunakan pada data yang bersifat fluktuatif atau tidak menunjukan keadaan trend (makridakis, dkk: 1999).

Pada dasarnya semua dokumen rekam medis sama, namun inovasi-inovasi bisa dilakukan instansi pelayanan kesehatan untuk memudahkan identifikasi misalnya kode warna. Huffman (1999) menyebutkan bahwa keseluruhan folder juga bisa berwarna untuk mempercepat penemuan visual. Dimana sampul dari dokumen diberi warna sesuai kelompok jenis kelamin atau berdasarkan jenis penyakit, untuk meminimalisir terjadinya kesalahan peletakan dan pengambilan dokumen.

Badan Layanan Umum Daerah (BLUD) RSU Kota Banjar merupakan salah satu rumah sakit di Provinsi Jawa Barat dengan angka kunjungan rawat inap yang terus meningkat setiap periodenya. Dalam pengelolaan rekam medisnya, BLUD RSU Kota Banjar menerapkan sistem pewarnaan dokumen rawat inap yaitu terdapat empat varian warna disesuaikan dengan jenis penyakitnya.Berdasarkan hasil wawancara dengan kepala rekam medis BLUD RSU Kota Banjar bahwa penerapan sistem pewarnaan pada dokumen rekam medis adalah hasil modifikasi dengan tujuan untuk mempermudah pencarian, dirasakan sangat membantu pekerjaan petugas dalam pengambilan berkas. Terlepas dari keuntungan yang didapatkan, pihak unit rekam medis menemukan kendala seperti kehabisan dokumen rekam medis, sehingga warna dokumen yang seharusnya akan digantikan dengan warna lainnya.

Survey pendahuluan yang dilakukan oleh peneliti diperoleh data perencanaan dokumen rekam medis warna putih (kasus perinatologi) tahun 2012 sebanyak 1750 buah, namun jumlah kunjungan pada tahun tersebut untuk kasus perinatologi sebanyak 3879, sehingga kekurangan 2129 dokumen warna putih, jelaslah metode perhitungan yang dilakukan pihak rumah sakit kurang efektif. Kemudian peneliti melakukan prediksi ulang pada tahun yang sama 
dengan menggunakan metode ARIMA didapatkan hasil prediksi 3910 dengan MSE 1003,6. Jumlah tersebut memenuhi kunjungan pasien perinatologi tahun 2012. Sebanyak 3879 pasien. Bahkan hasil perhitungan hanya memiliki selisih, yaitu lebih 31 saja dari jumlah kunjungan pasien baru rawat inap. Kekurangan dokumen terjadi pula pada tahun 2013 dan 2014 dimana stok yang diajukan tidak sesuai dengan jumlah kunjungan pasien baru. Kekurangan dokumen dapat menghambat pelayanan dan terjadinya kesalahan pewarnaan dokumen, sehingga perlu dilakukan perhitungan sesuai metode yang baku. Berdasarkan studi awal sangatlah tepat jika digunakan metode ARIMA.

Beranjak dari kondisi tersebut maka, peneliti melakukan kajian metode peralaman untuk dokumen rekam medis rawat inap berdasarkan varian warna di Rumah Sakit BLUD Kota Banjar untuk periode 2014-2015.

\section{METODE}

Jenis penelitian adalah kuantitatif, yaitu penelitian yang banyak ditunt ut menguakan angka, mulai dari pengumpulan data, penafsiran terhadap data tersebut, serta penampilan hasilnya.lingkup kontekstual yang spesifik. Subyek dari penelitian ini adalah rekapitulasi data kunjungan pasien baru perbangsal rawat inap. Populasi penelitian ini adalah jumlah kunjungan pasien perbangsal rawat inap tahun 2009 - Maret 2014 sesuai dengan ketentuan untuk melakukan prediksi yaitu lima tahun data sebelumnya yaitu sebanyak 100.971 pasien dengan rincian 17.765 pasien pada tahun 2009, 16.824 pasien pada tahun 2010, 19.571 pasien pada tahun 2011, 22.608 pasien pada tahun 2012, 24.203 pasien pada tahun 2013 dan 5693 pasien pada tahun 2014. Teknik sampel yang digunakan adalah total sample yaitu seluruh populasi yaitu data rekapitulasi laporan kunjungan pasien baru rawat inap tahun 2009-Maret 2014 yaitu sebanyak 107.664 pasien.Variabel yang digunakan adalah univariat yaitu prediksi kunjungan pasien baru per bangsal rawat inap BLUD RSU Kota Banjar.

\section{HASIL}

\section{Penyediaan Dokumen Rekam Medis Rawat Inap di BLUD RSU Kota Banjar}

Dokumen rekam medis rawat inap di BLUD RSU Kota Banjar diterapkan sistem pewarnaan sampul, yang terbagi dalam empat kategori warna dari ke 14 bangsal. Kategori tersebut dikelompokan berdasarkan jenis penyakit dan bangsal, berikut kategori warna beserta nama bangsalnya.

Tabel 1 Kategori Warna Dokumen Rekam Medis Rawat Inap

\begin{tabular}{cll}
\hline No & Warna & \multicolumn{1}{c}{ Bangsal } \\
\hline 1 & Pink & Teratai I, Teratai II \\
2 & Putih & Tulip \\
3 & Abu & Tanjung, Raflesia, Flamboyan \\
4 & Kuning & Dahlia, Mawar, Kenanga, ICU Melati, \\
& & Bougenvil, Wijayakusuma, Anggrek \\
\hline
\end{tabular}

Penentuan kebutuhan penyediaan dokumen rekam medis di BLUD RSU Kota Banjar dilakukan oleh kepala rekam medis yang diajukan kepada bagian perencanaan. Perhitungan dilakukan setiap satu tahun sekali, namun sampai saat ini kebijakan tentang perhitungan penyediaan dokumen rekam medis belum memiliki metode yang baku melainkan petugas menggunakan jumlah kunjungan pasien baru tahun sebelumnya untuk dijadikan patokan.

\section{Pola Data dan Prediksi Jumlah Kun- jungan Pasien Baru Perbangsal Rawat Inap di BLUD Kota Banjar}

Prediksi jumlah kunjungan dilakukan terhadap 14 bangsal yang ada di BLUD Kota Banjar dengan menyertakan jumlah kunjungan pasien baru perbulan dari Januari 2009 - maret 2014. Hasil Penelitian disajikan melalui grafik garis guna melihat kecenderungan pola untuk menetukan hasil prediksi.

a. Prediksi Kunjungan pasien baru pada bangsal Teratai



Gambar 1 Plot aktual data kunjungan pasien baru Bangsal Teratai 
Gambar 1 merupakan grafik kunjungan pasien baru dari dua bangsal yaitu Teratai I dan Teratai II yang pada bulan Nopember 2012 dilakukan penggabungan bangsal. Plot aktual data menunjukkan tidak stasioner dalam mean karena plot garis sangat signifikan perbedaannya (fluktuatif) berubah-ubah).

Prediksi jumlah kunjungan pasien baru bangsal teratai dengan menggunakan metode Autoregressive Integrated Moving Average (ARIMA) dengan model terbaik p,d,q $(1,0,0)$ didapatkan parameter AR 0,000 , nilai konstana 0,000, Mean Square Error (MSE) 0,000097 tetapi tidak stasioner dalam varian dengan hasil nilai lambda 0,56 (posisi berada di tengah-tengah antara 0-1) sehingga perlu ditransformasikan dalam bentuk square root . Berdasarkan hasil Prediksi maka didapatkan hasil jumlah kunjungan pasien baru bangsal Teratai tahun 2015 yaitu sebanyak 4437 pasien, jika dilihat dari plot peramalan maka hasil peramalan untuk tahun 2015 terlihat menurun dari tahun sebelumnya.

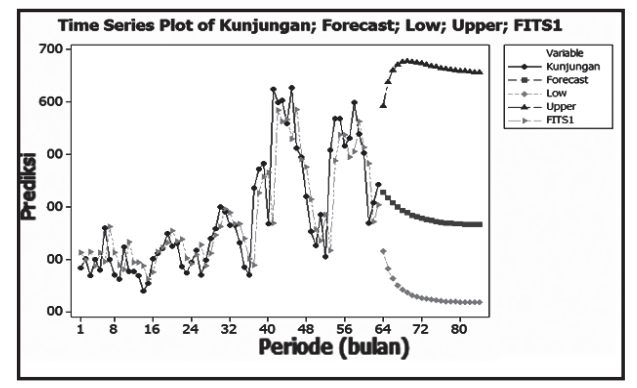

Gambar 2 Plot Prediksi Bangsal Teratai

b. Prediksi Kunjungan pasien baru pada bangsal Tulip

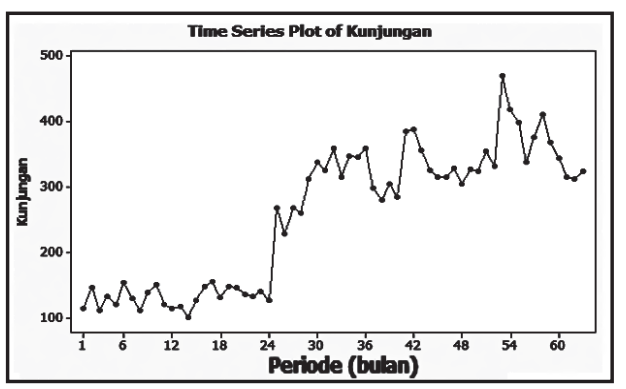

Gambar 3 Plot aktual data kunjungan pasien baru Bangsal Tulip
Gambar 3 meruakan grafik kunjungan pasien baru bangsal Tulip yaitu khusus penyakit perinatologi. Berdasarkan plot tersebut bahwa jumlah kunjungan pasien baru terlihat berubah-ubah kenaikan yang signifikan terjadi pada periode ke-25 dari bulan Desember 2010 ke Bulan Januari 2011 dengan kenaikan 141 pasien.

Prediksi jumlah kunjungan pasien baru bangsal tulip dengan menggunakan ARIMA model terbaik p,d,q $(1,1,0)$ yang memiliki nilai AR 0,010, nilai konstanta 0,011, nilai Mean Square Error (MSE) 1,3044 dan nilai lambda 0,44 (berada antara 0-1).

Berdasarkan hasil Prediksi maka didapatkan jumlah kunjungan pasien baru bangsal Tulip tahun 2015 sebanyak 4641 pasien, dengan pola trend meningkat dari setiap periodenya.



Gambar 4 Plot Prediksi Bangsal Tulip

c. Prediksi Kunjungan pasien baru pada bangsal Tanjung

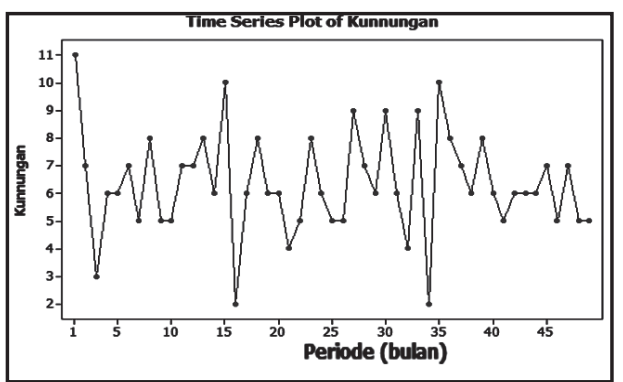

Gambar 5 Plot aktual data kunjungan pasien Baru Bangsal Tanjung

Gambar 5 menunjukan grafik kunjungan pasien baru bangsal Tanjung yaitu khusus penyakit jiwa atau psikiatri. Berdasarkan plot aktual data kunjungan pasien baru perbulan dari bulan Maret 2010 sampai bulan Maret 2014 terlihat bahwa jumlah 
kunjungan pasien baru menunjukan fluktuatif/berubah-ubah kenaikan yang tidak begitu signifikan atau mendekati keadaan stasioner.

Prediksi jumlah kunjungan pasien baru bangsal Tanjung menggunakan metode ARIMA dengan model terbaik $\mathrm{p}, \mathrm{d}, \mathrm{q}$ $(1,1,1)$ mempunyai nilai AR 0,026 dan MA 0,000, tidak menggunakan nilai konstanta,mempunyai nilai Mean Square Error (MSE) 3,033 dan stasioner dalam varian dengan nilai lambda 0,87 .

Berdasarkan hasil Prediksi maka didapatkan jumlah kunjungan pasien baru bangsal Tanjung tahun 2015 yaitu sebanyak 76 pasien, dengan pola trend tetap dari setiap periodenya.

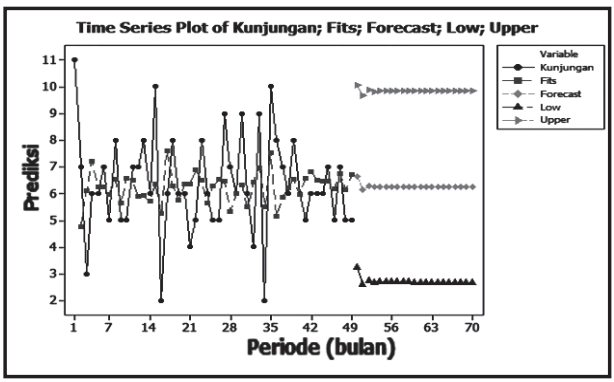

Gambar 6 Plot Prediksi Bangsal Tanjung

d. Prediksi Kunjungan pasien baru pada bangsal Raflesia



Gambar 7 Plot aktual data kunjungan pasien baru Bangsal Raflesia

Gambar 7 menunjukan grafik kunjungan pasien baru bangsal Raflesia yaitu khusus penyakit Ortophedi/Bedah Syaraf. Berdasarkan plot aktual data kunjungan pasien baru perbulan dari bulan Juni 2009 sampai bulan Maret 2014 terlihat bahwa jumlah kunjungan pasien baru menunjukan fluktuatif/berubah-ubah, kenaikan yang begitu signifikan terjadi pada periode ke-
45 yaitu pada bulan Februari 2013 dengan kenaikan 19 pasien.

Prediksi kunjungan pasien baru bangsal Raflesia menggunakan metode ARIMA dengan model terbaik p,d,q $(1,1,1)$ memiliki nilai AR 0,001 dan MA 0,000, nilai konstanta 0,001 , nilai MSE 179,46 dan sudah stasioner dalam varian (nilai lambda 1,17).

Berdasarkan hasil Prediksi maka didapatkan jumlah kunjungan pasien baru bangsal Raflesia tahun 2015 yaitu sebanyak 1258 pasien, dengan pola trend meningkat dari setiap periodenya.



Gambar 8 Plot Prediksi Bangsal Raflesia

e. Prediksi Kunjungan pasien baru pada bangsal Flamboyan

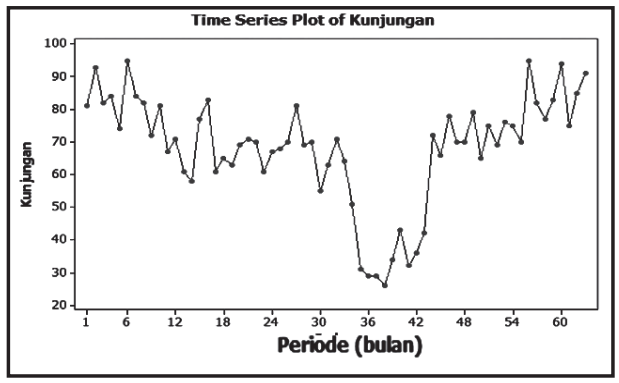

Gambar 9 Plot aktual data kunjungan pasien baru Bangsal Flamboyan

Gambar 9 menunjukan grafik kunjungan pasien baru bangsal Flamboyan yaitu khusus penyakit Stroke/Syaraf. Berdasarkan plot aktual data kunjungan pasien baru perbulan dari bulan Januari 2009 sampai bulan Maret 2014 terlihat bahwa jumlah kunjungan pasien baru menunjukan fluktuatif/berubahubah, terjadi penurunan yang signifikan pada periode ke-35 dan kembali stabil pada periode ke-45. 
Dengan model ARIMA $(1,0,0)$ dengan nilai Ar 0,000, nilai konstanta 0,000, nilai MSE 0,4134 dan nilai lambda 0,56 sehingga perlu ditransformasikan kedalam bentuk square root sehingga hasil akhir peramalan perlu dirubah kembali dengan mengkuadratkan nilai square root.

Berdasarkan hasil Prediksi maka didapatkan jumlah kunjungan pasien baru bangsal Flamboyan tahun 2015 yaitu sebanyak 852 pasien, dengan pola trend menurun dari setiap periodenya.

f. Prediksi Kunjungan pasien baru pada bangsal Dahlia

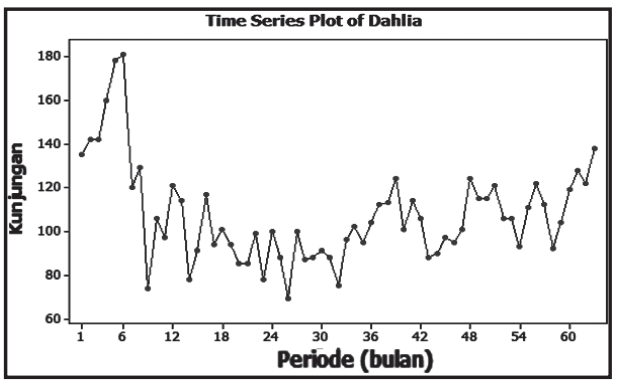

Gambar 10 Plot aktual data kunjungan pasien baru Bangsal Dahlia

Gambar 10 menunjukan grafik kunjungan pasien baru dari bangsal Dahlia (penyakit dalam). Berdasarkan plot aktual data kunjungan pasien baru terlihat bahwa data tersebut tidak stasioner dalam mean, dengan jumlah kunjungan menunjukan cenderung menurun kemudian stabil.

Prediksi ini dilakukan dengan metode ARIMA, didpatkan model terbaiknya p,d,q $(0,1,1)$ dengan nilai MA 0,001, nilai konstan tidak signifikan, nilai MSE nya 282,5 dan memiliki nilai lambda 1,00 maka data tidak perlu ditransformasikan.

Hasil prediksi didapatkan jumlah kunjungan pasien baru bangsal Dahlia tahun 2015 sebanyak 1608 pasien, grafik peramalan menunjukan bahwa kunjungan pasien baru bangsal Dahlia setiap bulannya sama/datar.

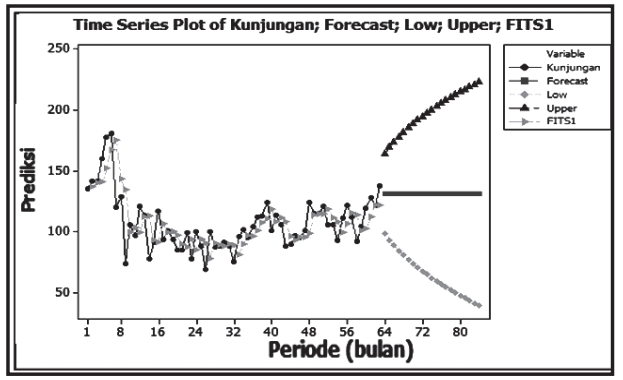

Gambar 11 Plot Prediksi Bangsal Dahlia

g. Prediksi Kunjungan pasien baru pada bangsal Kenanga

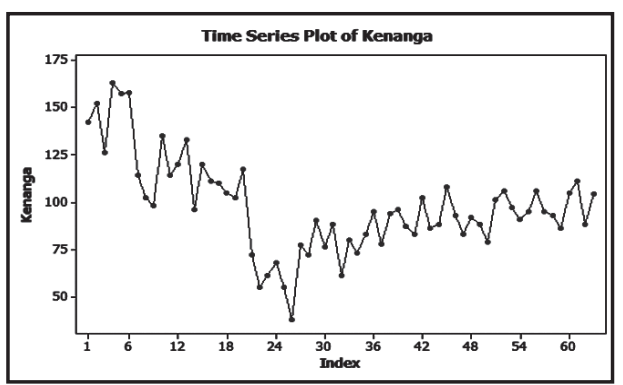

Gambar 12 Plot aktual data kunjungan pasien baru Bangsal Kenanga

Gambar 12 menunjukan grafik kunjungan pasien barudaribangsal Kenanga untukpasien penyakit dalam. Berdasarkan plot aktual data kunjungan pasien baru terlihat bahwa grafik tidakstasioner dalam mean, jumlah kunjungan pasien baru menunjukan fluktuatif/berubahubah cenderung turun kemudian konstan.

Model yang cocok untuk melakukan prediksi jumlah kunjungan pasien baru bangsal Kenanga adalah p,d,q $(0,1,1)$ dengan memiliki nilai MA0,000, nilai konstan tidak signifikan, nilai MSE 256,0 dan nilai lambda 0,88.

Berdasarkan hasil Prediksi maka didapatkan hasil jumlah kunjungan pasien baru bangsal Kenanga tahun 2015 yaitu sebanyak 1201 pasien, pada grafik peramalan menunjukan hasil yang datar dengan jumlah kunjungan perbulannya sama yaitu 100 orang.



Gambar 13 Plot Prediksi Bangsal Kenanga 
h. Prediksi Kunjungan pasien baru pada bangsal Anggrek

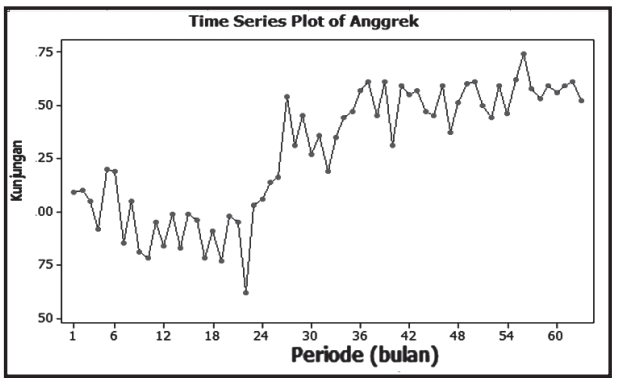

Gambar 14 Plot aktual data kunjungan pasien baru Bangsal Anggrek

Gambar tersebut menunjukan grafik kunjungan pasien baru dari bangsal Anggrek untuk pasien penyakit dalam. Berdasarkan plot aktual data kunjungan pasien baru terlihat bahwa data belum stasioner dalam mean, jumlah kunjungan pasien baru menunjukan fluktuatif/ berubah-ubah cenderung naik kemudian konstan.

Metode yang digunakan untuk melakukan peramalan adalah ARIMA, dengan model terbaiknya $p, d, q(0,1,1)$ memiliki nilai MA 0,000 , nilai konstanta tidak signifikan, mempunyai nilai MSE 188,8 dan nilai lambda 1,77 .

Berdasarkan hasil Prediksi maka didapatkan hasil jumlah kunjungan pasien baru bangsal Anggrek tahun 2015 yaitu sebanyak 1873 pasien, kunjungan pasien baru perbulannya diramalkan akan sama yaitu 156 pasien.



Gambar 15 Plot Prediksi Bangsal Anggrek

i. Prediksi Kunjungan pasien baru pada bangsal Bougenvil



Gambar 16 Plot aktual data kunjungan pasien baru Bangsal Bougenvil

Gambar tersebut menunjukan grafik kunjungan pasien baru dari bangsal Bougenvil untuk pasien penyakit dalam. Berdasarkan plot aktual data kunjungan pasien baru terlihat bahwa dat a tidak stasioner dalam mean, jumlah kunjungan pasien baru menunjukan fluktuatif/berubah-ubah cenderung konstan.

Metode yang digunakan untuk melakukan peramalan adalah ARIMA, dengan model terbaiknya $\mathrm{p}, \mathrm{d}, \mathrm{q}(1,1,1)$ yang mempunyai nilai AR dan MA nya masing masing 0,021 dan 0,000, nilai konstanta tidak signifikan, nilai MSE 162,03 dan nilai lambda 1,30 .

Berdasarkan hasil Prediksi maka didapatkan hasil jumlah kunjungan pasien baru bangsal Bougenvil tahun 2015 yaitu sebanyak 1508 pasien, dengan jumlah kunjungan perbulannya sama atau menunjukan keadaan flat.



Gambar 17 Plot Prediksi Bangsal Bougenvil

j. Prediksi Kunjungan pasien baru pada bangsal Melati 


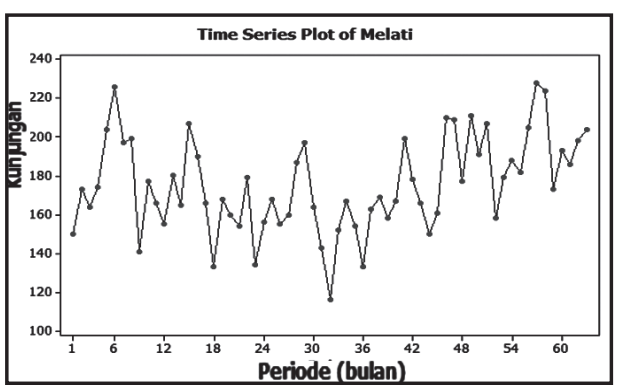

Gambar 18 Plot aktual data kunjungan pasien baru Bangsal Melati

Gambar grafik kunjungan pasien baru dari bangsal Melati untuk pasien penyakit anak diatas terlihat bahwa plot aktual data kunjungan pasien tidak stasioner dalam mean, jumlah kunjungan pasien baru menunjukan fluktuatif/berubah-ubah.

Metode yang digunakan untuk melakukan peramalan adalah ARIMA, dengan model terbaiknya $\mathrm{p}, \mathrm{d}, \mathrm{q}(1,1,1)$ yang mempunyai nilai AR dan Ma masing masing 0,000, nilai konstanta 0,001, nilai MSE 465,0 dan nilai lambda 1,30 .

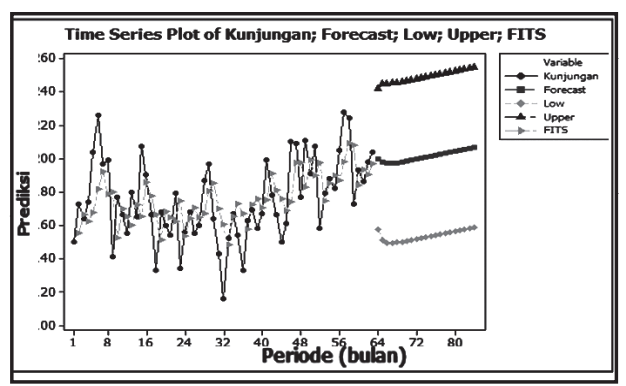

Gambar 19 Plot Prediksi Bangsal Melati

k. Prediksi Kunjungan pasien baru pada bangsal Wijayakusuma



Gambar 20. Plot aktual data kunjungan pasien baru Bangsal Wijayakusuma

Berdasarkan plot aktual data kunjungan pasien baru Wijayakusuma (Bedah umum) terlihat bahwa data tidak stasioner dalam mean, jumlah kunjungan pasien baru menunjukan fluktuatif/berubah-ubah cenderung turun kemudian konstan.

Metode yang digunakan untuk melakukan peramalan adalah ARIMA, dengan model terbaiknya $\mathrm{p}, \mathrm{d}, \mathrm{q}(3,1,1)$ yang mempunyai nilai AR 0,008 dan MA 0,000, nilai konstanta 0,010, nilai MSE 620,1 dan nilai lambda 0,87 .

Berdasarkan hasil Prediksi maka didapatkan hasil jumlah kunjungan pasien baru bangsal Wijayakusuma tahun 2015 yaitu sebanyak 1197 pasien dengan hasil cenderung turun.



Gambar 21.Plot Prediksi Bangsal Wijayakusuma

l. Prediksi Kunjungan pasien baru pada bangsal ICU

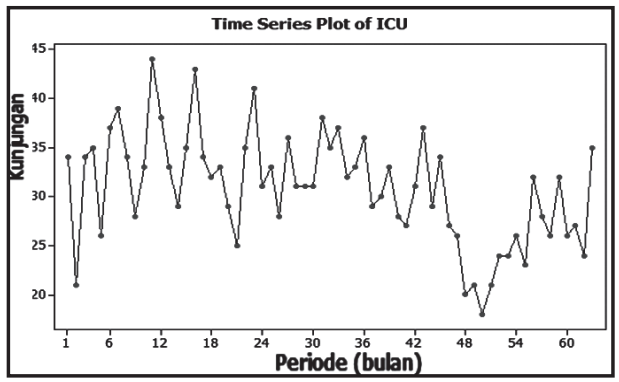

Gambar 22 Plot aktual data kunjungan pasien baru Bangsal ICU

Gambar tersebut menunjukan grafik kunjungan pasien baru dari bangsal ICU untuk pasien ICU. Berdasarkan plot aktual data kunjungan pasien baru terlihat bahwa data tidak stasioner dalam mean, jumlah kunjungan pasien baru menunjukan fluktuatif/berubah-ubah.

Metode yang digunakan untuk melakukan peramalan adalah ARIMA, dengan model terbaiknya $\mathrm{p}, \mathrm{d}, \mathrm{q}(0,1,1)$ yang mempunyai nilai MA 0,000 , nilai konstanta tidak signifikan, nilai MSE 0,02730 dan 
nilai lambda 0,06 sehingga data harus ditransformasikan dalam bentuk log.

Berdasarkan hasil Prediksi maka didapatkan hasil jumlah kunjungan pasien baru bangsal ICU tahun 2015 yaitu sebanyak 343 pasien dengan hasil cenderung datar.

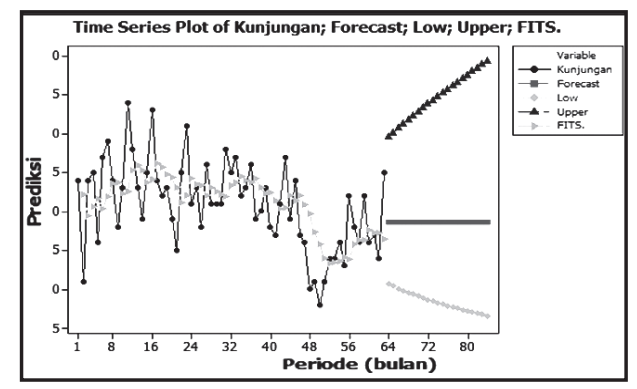

Gambar 23. Plot Prediksi Bangsal ICU

m. Prediksi Kunjungan pasien baru pada bangsal Mawar

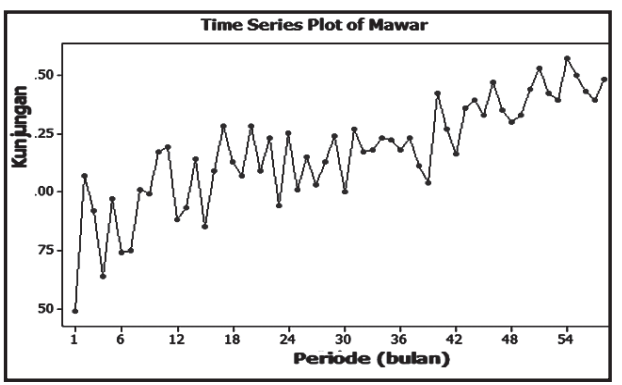

Gambar 24. Plot aktual data kunjungan pasien baru Bangsal Mawar

Gambar 24 menunjukan grafik kunjungan pasien baru dari bangsal Mawar untuk pasien penyakit dalam. Berdasarkan plot aktual data kunjungan pasien baru terlihat bahwa jumlah kunjungan pasien baru menunjukan flukt uatif/berubah-ubah cenderung naik.

Metode yang digunakan untuk melakukan peramalan adalah ARIMA, dengan model terbaiknya p,d,q $(0,1,1)$ yang mempunyai nilai MA 0,000 , nilai konstanta 0,010, nilai MSE 149,91 dan nilai lambda 1,45 .

Berdasarkan hasil Prediksi diatas maka didapatkan hasil jumlah kunjungan pasien baru bangsal Mawar tahun 2015 yaitu sebanyak 1981 pasien dengan hasil cenderung naik.



Gambar 25. Plot Prediksi Bangsal Mawar

\section{Kebutuhan Dokumen Rekam Medis Tahun 2015}

Setiap pasien baru akan mendapatkan satu dokumen rekam medis, oleh sebab itu untuk mengetahui jumlah kebutuhan penyediaan dokumen rekam medis disesuaikan dengan jumlah kunjungan pasien baru pada periode tersebut. Untuk mengetahui kebutuhan penyediaan dokumen rekam medis pada tahun 2015 maka jumlah yang digunakan adalah hasil hasil prediksi jumlah kunjungan pasien baru perbangsal rawat inap tahun 2015 berdasarkan perhitungan dengan menggunakan metode Autoregressive Integrated Moving Average (ARIMA).

Hasil perhitungan perbangsal akan dikelompokan berdasarkan warna dokumen untuk mempermudah dalam mengetahui jumlahnya, didapatkan hasil sebagai berikut:

Tabel 2 Rekapitulasi Hasil Prediksi Kunjungan Pasien Baru Perbangsal Rawat Inap Tahun 2015

\begin{tabular}{|c|c|c|c|c|}
\hline No & $\begin{array}{c}\text { Warna } \\
\text { DRM }\end{array}$ & Bangsal & Prediksi & Jumlah \\
\hline 1 & Pink & Teratai & 4437 & 4437 \\
\hline 2 & Putih & Tulip & 4641 & 4641 \\
\hline \multirow[t]{3}{*}{3} & $\mathrm{Abu}$ & Tanjung & 76 & \\
\hline & & Raflesia & 1258 & 2185 \\
\hline & & Flamboyan & 852 & \\
\hline \multirow[t]{9}{*}{4} & Kuning & Dahlia & 1608 & \\
\hline & & Kenanga & 1201 & \\
\hline & & Anggrek & 1873 & \\
\hline & & Bougenvil & 1508 & 12152 \\
\hline & & Melati & 2441 & \\
\hline & & Wijayakusuma & 1197 & \\
\hline & & ICU & 343 & \\
\hline & & Mawar & 1981 & \\
\hline & & Total Prediksi & & 23415 \\
\hline
\end{tabular}


Berdasarkan penyajian tabel diatas maka jumlah prediksi kunjungan pasien baru perbangsal rawat inap pada tahun 2015 adalah 23415. Penyediaan dokumen rekam medis yang diperlukan medis sebanayak 23415 dengan warna terbanyak yaitu kuning sebanyak 12152 buah dan terkecil yaitu abu sebanyak 2185 buah.

\section{PEMBAHASAN}

\section{Pola Data Kunjungan Pasien Baru Per- bangsal Rawat Inap Tahun 2009-2013 di BLUD RSU Kota Banjar}

Jumlah kunjungan pasien baru rawat inap dari tahun 2009-Maret 2014 mengalami fluktuatif (naik-turun) yang terjadi pada semua bangsal. Pola data tersebut diambil dari pergerakan angka kunjungan perbulannnya karena berkaitan dengan periode yang akan di prediksi yaitu berdasarkan bulan pada tahun 2014 dan 2015 .

Keadaan fluktuatif ini menandakan bahwa prediksi ini dapat digunakan dengan menggunakan metode ARIMA Hal ini selaras dengan pernyataan Makridakis, dkk (1999) bahwa Model ARIMA sangat baik digunakan pada data yang bersifat fluktuatif atau tidak menunjukan keadaan trend, dengan pemilihan secara iteratif maka hasil peramalan akan disesuaikan dengan data historis.

Berdasarkan pernyataan salah satu petugas rumah sakit keadaan jumlah kunjungan rawat inap yang fluktuatif dipengaruhi oleh beberapa faktor antara lain: permintaan jumlah pasien untuk dirawat inap, adanya penambahan jumlah tempat tidur sebanyak 3 buah pada tahun 2012, jumlah petugas medis, kepuasan pasien terhadap pelayanan dan ketersediaan fasilitas-fasilitas penunjang.

\section{Prediksi Kunjungan Pasien Baru Per- bangsal Rawat Inap Tahun 2015}

Metode ARIMA baik digunakan jika data sudah stasioner dalam mean dan varian, dari hasil pemeriksaan/checking terhadap data pada seluruh bangsal menunjukan keadaan yang tidak stasioner dalam mean, karena nilai a pada uji 1-sample $\bar{t} 0,05$ yang mengharuskan data harus dilakukan pembedaan/difference sehingga nilai orde $\mathrm{d}$ menjadi 0 atau 1 .

Stasioner dalam varian pada data bangsal rawat inap dilihat dari nilai lambda pada uji Box-cox transformation. Dari hasil pengolahan, bangsal yang tidak stasioner dalam varian yaitu yang mempunyai nilai lambda ë (tidak mendekati) 1 , adalah bangsal Teratai, bangsal Tulip, bangsal Flamboyan dan ICU sehingga data akan di transformasi menjadi bentuk square root (akar) atau dalam bentuk log.

Hasil peramalan secara keseluruhan pada tahun 2015 adalah 23415 pasien baru, jumlah ini cenderung turun dari tahun 2013 dengan kunjungan 24203 sebesar 808 poin dan naik dari hasil prediksi tahun 2014 dengan kunjungan 23111 sebesar 284 poin, hal ini menunjukan fluktuatif setiap tahunnya.

Berdasarkan hasil peramalan diatas jika dilihat dari plot peramalan perbulan tahun 2015 didapatkan ada beberapa bangsal dengan plot meningkat seperti bangsal Tulip, bangsal Mawar, bangsal Raflesia dan bangsal Melati. Plot yang turun terjadi pada bangsal Wijayakusuma, bangsal Teratai dan bangsal Flamboyan. Bangsal yang hasil peramalannya flat/datar perbulan pada tahun 2015, seperti pada bangsal Tanjung, bangsal Dahlia, bangsal Kenanga, bangsal Anggrek, bangsal Bougenvil dan bangsal ICU.

Menurut Makridakis, dkk (1999) untuk peramalan jangka panjang dan menengah ketepatan peramalannya kurang baik. Biasanya akan cenderung flat (mendatar/konstan). Namun, hasilflat tersebut tidak semata-mata dipengaruhi oleh jumlah periode peramalannya. Akan tetapi ada beberapa faktor yang mempengaruhi flat/ tidaknya hasil peramalan seperti model terbaik ARIMA yang memiliki nilai MSE terkecil tetapi angka konstan nya tidak signifikan atau $\mathrm{a}^{-} 0,05$, pada model yang nilai konstannya tidak signifikan. Penggunaan konstan dapat menambahkan pola trend atau musiman pada hasil peramalan.

Include constant in this model at au penggunaan nilai konstan pada model ARIMA dipakai ketika data historisnya menunjukan fluktuatif yang signifikan, sehingga perlu digunakan nilai konstan untuk menambah pola trend dan 
musiman pada hasil peramalan (Iriawan $\mathrm{N}$ dan Astuti, 2006).

Sejalan dengan pernyataan dari Iriawan dan Astuti maka ketika data historis menunjukan plot yang hampir konstan/stabil maka tidak diperlukan lagi penambahan nilai konstanta, sehingga besar kemungkinan hasil peramalannya akan flat.

Hasil peramalan dengan pola flat bukan berarti hasil peramalan tidak baik, namun jika dilihat dari sudut pandang lain tentang peramalan yaitu hal yang belum pasti kebenarannya, maka langkah kita sebagai peramal harus mengasumsikan setiap periodenya stabil. Sehingga perbedaan yang mungkin akan terjadi tidak begitu signifikan, hal ini sejalan dengan pernyataan Setiadi dalam bukunya peramalan untuk bisnis.

Menurut Setiadi (2003) bahwa peramalan identik dengan hal yang penuh ketidakpastian. Maka perlu merubah situasi kedalam situasi yang setara (ekuivalen) dan menganggap peristiwa yang akan terjadi tersebut akan jatuh pada daerah tertentu yang masih berada didaerah toleransi (dalam range tertentu yang masih dapat diterima). Misalnya dengan menganggap/ mengasumsikan bahwa situasi dan kondisi cenderung konstan.

\section{Kebutuhan Penyediaan Dokumen Rekam Medis Berdasarkan Warna Dokumen}

Kebutuhan penyediaan dokumen rekam medis erat kaitannya dengan jumlah kunjungan pasien baru karena setiap pasien baru yang akan dirawat tentunya akan diberikan satu buah dokumen rekam medis, pewarnaan sampul yang digunakan oleh pihak BLUD RSU Banjar meliputi empat warna yang berdasarkan jenis penyakitnya.

Pemberlakuan pewarnaan dokumen rekam medis tentunya sangat berpengaruh terhadap jumlah penyediaan dokumen perwarnanya, diharapkan jumlah yang disediakan cukup untuk satu tahun. Jika salah satu warna kurang maka akan digantikan dengan warna lain yang tentunya sedikit menyulitkan petugas ketika proses pengambilan kembali dokumen.
Berdasarkan hasil prediksi jumlah penyediaan dokumen rekam medis pada tahun 2015 adalah 23415 buah, dengan rincian sebagai berikut : pink 4437 buah, putih 4641 buah, abu 2185 buah dan kuning 12152 buah. Jumlah tersebut masih dalam batas wajar karena tidak berbeda jauh dengan penyediaan dokumen pada tahun-tahun sebelumnya, berikut data penyediaan dokumen rekam medis pada tahun 2009-2014.

Tabel 3 Data penyediaan dokumen rekam medis BLUD RSU Kota Banjar

\begin{tabular}{|c|c|c|c|c|c|}
\hline Warna & \multirow{2}{*}{ Pink } & Putih & Abu & Kuning & Jumlah \\
\cline { 1 - 5 } Tahun & & & & & \\
\hline 2009 & 1800 & 1700 & 1200 & 10600 & 15300 \\
\hline 2010 & 1600 & 1600 & 1200 & 13000 & 17400 \\
\hline 2011 & 1600 & 1600 & 1200 & 13000 & 17400 \\
\hline 2012 & 2000 & 1750 & 1100 & 13000 & 17850 \\
\hline 2013 & 4000 & 4000 & 1100 & 15000 & 24100 \\
\hline 2014 & 4500 & 3750 & 1400 & 12000 & 21650 \\
\hline 2015 & 4437 & 4641 & 2185 & 12152 & 23415 \\
\hline
\end{tabular}

Berdasarkan tabel diatas dapat kita lihat bahwa jumlah penyediaan pada tahun 2015 masih berada di bawah nilai tertinggi sehingga jika penyediaan terkendala dengan penyesuaian RAB maka jumlah tersebut masih bisa di terima. Yang membedakan dari penyediaan diatas adalah proporsi tiap warnanya karena jumlah penyediaan dokumen yang dilakukan oleh pihak rumah sakit Banjar, sering tidak sesuai dengan jumlah kunjungannya, berikut ini tabel kompilasi antara penyediaan dokumen dengan jumlah kunjungan:

Tabel 4. Perbandingan antara penyediaan dokumen dengan jumlah kunjungan

\begin{tabular}{lllll}
\hline Warna & Tahun & $\begin{array}{c}\text { Penye- } \\
\text { diaan }\end{array}$ & $\begin{array}{c}\text { Jml } \\
\text { Kunjungan }\end{array}$ & Selisih \\
\hline Pink & 2009 & 1800 & 3505 & -1705 \\
& 2010 & 1600 & 3563 & -1963 \\
& 2011 & 1600 & 3994 & -2394 \\
& 2012 & 2000 & 6203 & -4203 \\
& 2013 & 4000 & 5708 & -1708 \\
Putih & 2009 & 1700 & 1545 & 155 \\
& 2010 & 1600 & 1604 & -4 \\
& 2011 & 1600 & 3720 & -2120 \\
& 2012 & 1750 & 3879 & -2129 \\
& 2013 & 4000 & 4456 & -456 \\
& 2009 & 1200 & 1412 & -212 \\
& 2010 & 1200 & 1650 & -450 \\
& 2011 & 1200 & 1703 & -503 \\
\hline
\end{tabular}




\begin{tabular}{lllll}
\hline Warna & Tahun & $\begin{array}{c}\text { Penye- } \\
\text { diaan }\end{array}$ & $\begin{array}{c}\text { Jml } \\
\text { Kunjungan }\end{array}$ & Selisih \\
\hline \multirow{4}{*}{ Kuning } & 2012 & 1100 & 1425 & -325 \\
& 2013 & 1100 & 2232 & -1132 \\
& 2009 & 10600 & 10891 & -291 \\
& 2010 & 13000 & 9977 & 3023 \\
& 2011 & 13000 & 10148 & 2852 \\
& 2012 & 13000 & 10996 & 2004 \\
& 2013 & 15000 & 11807 & 3193 \\
\hline
\end{tabular}

Berdasarkan penyajian tabel diatas dapat kita lihat bahwa penyediaan dokumen rekam medis kecenderungan sering tidak sesuai seperti yang terjadi pada penyediaan dokumen rekam medis warna kuning setiap tahunnya sering lebih dari jumlah kunjungannya, sehingga menghasilkan banyak sisa, biasanya sisa tersebut digunakan sebagai stok untuk periode yang akan datang dan digunakan untuk mengganti warna lain yang kehabisan stok.

Kondisi ini berbanding terbalik dengan warna dokumen rekam medis lainnya, yang sering kekurangan stok dokumen akibat kunjungan pasien lebih tinggi dari penyediaan dokumen. Akibatnya dokumen tersebut harus digantikan dengan warna lain.

Sebagai contoh adalah nampak nama bayi pasien bangsal Tulip menggunakan warna dokumen rekam medis kuning, seharusnya sesuai ketentuan untuk setiap pasien bayi/ perinatologi warna dokumennya adalah putih, tetapi karena pada saat itu stok dokumen warna putih kehabisan. Gambar ini diambil pada bulan Mei 2014 seharusnya stok dokumen habis pada saat bulan terakhir periode yaitu bulan Desember. Namun, pada bulan Mei stok warna putih sudah habis sehingga sampai akhir periode untuk pasien bangal Tulip akan diberikan dokumen warna kuning.

Kehabisan stok warna dokumen terpaksa harus digantikan dengan warna lain, akibatnya petugas akan sedikit kesulitan menemukan kembali dokumen yang akan digunakan, sebagai mana yang dijelaskan oleh Huffman (1999) menyebutkan bahwa keseluruhan folder juga bisa berwarna untuk mempercepat penemuan visual. Namun ketika pewarnaan tidak sesuai maka beban petugas dalam pencarian akan semakin bertambah.

\section{KESIMPULAN}

Berdasarkan hasil dan pembahasan, peneliti menyimpulkan:

1. Jumlah kunjungan pasien baru rawat inap dari tahun 2009-Maret 2014 mengalami fluktuatif (naik-turun) yang terjadi pada semua bangsal. Keadaan jumlah kunjungan rawat inap yang fluktuatif dipengaruhi oleh beberapa faktor antara lain: permintaan jumlah pasien untuk dirawat inap, adanya penambahan jumlah tempat tidur sebanyak 3 buah pada tahun 2012, jumlah petugas medis, kepuasan pasien terhadap pelayanan dan ketersediaan fasilitas-fasilitas penunjang.

2. Hasil prediksi jumlah kunjungan pasien baru perbangsal rawat inap tahun 2015 yang dikelompokan berdasarkan warna dokumen adalah 23415 dengan rincian sebagai berikut: warna pink untuk kasus kebidanan bangsal Teratai yaitu 4437 pasien, warna putih untuk kasus perinatologi bangsal Tulip sebanyak 4641 pasien, warna Abu untuk kasus syaraf meliputi bangsal Tanjung, Raflesia dan Flamboyan sebanyak 2185 pasien dan warna kuning sebanyak 12152 untuk kasus umum meliputi bangsal Dahlia, Kenanga, Anggrek, Bougenvil, Melati, Wijayakusuma, ICU dan Mawar.

\section{DAFTAR PUSTAKA}

Aditama, T.J. (2010). Manajemen Administrasi Rumah Sakit, Edisi Kedua. Jakarta: Universitas Indonesia.

Alamsyah, D. (2011). Manajemen Pelayanan Kesehatan. Yogyakarta: Nuha Medika.

Depkes RI. (2007). Pedoman Penyelenggaraan Pelayanan Di Rumah Sakit. Jakarta: Departemen Kesehatan RI.

Gemalla, R. H. (2008). Pedoman Manajemen Informasi Kesehatan di Sarana Pelayanan Kesehatan. Jakarta: Universitas Indonesia.

Huffman, E. (1999). Health Information Management Part, Terjemaahan dari Erkadakus. Jakarta

Irawan dan Astuti (2006). Mengolah Data Statistik dengan Mudah Menggunakan Minitab 14. Yogyakarta: C.V Andi Offset 
Lia, F. M., Wiwik, A., \& Retno, A.V. (2012). Prediksi Jumlah Kunjungan Pasien Rawat Jalan Menggunakan Metode Genetik Fuzzy Systems Studi Kasus: Rumah Sakit Usada Sidoarjo. Jurnal Teknik ITS

Makridakis, Spyros, dkk,. (1999). Metode dan Aplikasi Peramalan. Jilid I (Edisi Kedua), Terjemahan Ir. Hari Suminto. Jakarta: Bina Rupa Aksara.

Notoatmodjo, S .(2012). Metodologi Penelitian Kesehatan. Jakarta: PT Rineka Cipta.

Peraturan Menteri Kesehatan Republik Indonesia No.269/Menkes/Per/III/2008 tentang Rekam Medis. 2008. Jakarta.

Rosyiidah, dkk. (2005). Pemodelan ARIMA Dalam Peramalan Penumpang Kereta Api pada Daerah Operasi (DAOP) IX Jember. Jurnal Universitas Jember.
Saryono \& Anggraeni. (2013). Metode Penelitian Kualitatif dan Kuantitatif dalam bidang kesehatan. Yogyakarta: Nuha Medika.

Setiadi, N. (2003). Prakiraan Bisnis Pendekatan Analisis Kuantitatif untuk Antisipasi Bisnis. Bogor: Kencana.

Shofari. B. (2002). Buku 2 Sistem dan Prosedur Pelayanan Rekam medis. Semarang: Perhimpunan Nasional Perekam Medis dan Informasi Kesehatan Indonesia (PORMIKI).

Sony, S. (2010). Modul Time series. Semarang: Akademi Ilmu Statistika Muhammadiyah.

Sri, H. Antik, P. \& Riyokoi. (2009). Prediksi Kebutuhan Formulir Rekam Medis Rawat Inap Di RSUD Kabupaten Karanganyar. Jurnal Kesehatan . Vol 3, 1-21

Sunyoto, D. (2013). Statistik Untuk Paramedis. Bandung: Alfabeta. 